Nurşen Tanrıkulu $\odot$

Ali Haspolat $\odot$

Ali Şefik Köprülü ๑

Ergun Demirsoy ๑

\title{
Lower Respiratory Tract and Urinary System Colonization in Patients with Cardiovascular Surgery
}

Etik Kurul Onayı: Kolan Hastanesi Klinik Araştırmalar Etik Kurulu'ndan onay alınmıştı (01.01.2016).

Çıkar çatışması: Herhangi bir kişi, kurum ya da tüzel kişilikle çıkar çatışması bulunmamaktadır.

Finansal destek: Herhangi bir kişi, kurum ya da tüzel kişilikten finansal destek alınmamıştır. Hasta onamı: Hasta yatış onamında açık kimlik belli olmaksızın tıbbi verilerin eğitim, makale, kongre sunu vb. amaçlarla paylaşımına onam vardır.
Ethics Committee Approval: Approval was obtained from the Kolan Hospital Clinical Research Ethics Committee (01.01.2016).

Conflict of interest: There is no conflict of interest with any person, institution or legal entity. Financial support: No financial support has been received from any person, institution or legal entity.

Informed consent: At the patient's consent, there is consent to share medical data for purposes of education, article, congress presentation, etc., without clear identification.

Cite as: Tanrıkulu N, Haspolat A, Köprülü AŞ, Demirsoy E. Kardiyovaskuler cerrahi hastalarında alt solunum yolu ve üriner sistem kolonizasyonu. GKDA Derg. 2020;26(3):147-56.

öz

Amaç: Kardiyovasküler cerrahide postoperatif infeksiyonların önlenebilmesi preoperatif infeksiyonların tedavisiyle olasıdır. Ancak, klinik yakınması olmayan, tüm laboratuvar bulguları normal alt solunum yolu veya üriner sistem kolonizasyonu olan kültür (+) hastalarda üzerinde düșünce birliğine varılmıs rutin klinik protokol yoktur. Çalışmamızda, klinik muayene, laboratuvar bulguları normal olan hastalardan preoperatuvar alınan trakeal/idrar kültürlerinin sonuçlarını ve üreme saptanan kolonize hastalarda bunun kliniğe yansımasını irdeledik. Böylece major risk gruplarını tanımlamayı, olası klinik sonuçları paylaşmayı amaçladık.

Yöntem: Hastanemizde, Ocak 2016-Haziran 2019 arasındaki muayene bulguları ve laboratuvar bulgular normal olan KVC hastalarından ameliyattan önce trakeal/idrar kültürü alındı. Hastalar retrospektif olarak kültürlerinde üreme olmayan (G-I) ve olan (G-II) 2 gruba ayrılarak demografik bulgular, risk faktörleri, kros klamp-baypas pompa süreleri, yoğun bakım-hastane yatıs süresi, kan ürünleri tüketimi, majör komplikasyonlar, sistemik infeksiyon ve mortalite açısından karşılaştırıldı.

Bulgular: Tüm bulguların normal olduğu 307 hastanın 90'ında (\%61.11) üreme oldu. Trakeada en sık Pseudomonas (35), idrardaysa E.coli (13) üredi. Kadın cinsiyette kolonizasyon anlamlı yüksek bulundu. Komorbiditiler arasından DM, HT, kreatinin, albumin, EF, PAP değerleri arasında da fark saptanmazken, sigara içenler ve $K O A H^{\prime}$ lı hastalar G-Il grubunda anlamlı olarak daha fazlaydı. Ek olarak G-Il hastaların YВÜ/hastane kalış sürelerinin daha uzun olduğu, daha fazla kan ürünü tüketildiği, postoperatuvar dönemde daha yüksek oranda infeksiyon geliştiği saptandı. G-I'de majör komplikasyon olarak tam blok, ciddi aritmi, plevral efüzyon, G-II'deyse plevral efüzyon, ciddi aritmi, geçici iskemik atak, ileus olarak not edildi. Mortalite açısından istatistiki fark saptanmadı.

Sonuç: Sigara ve KOAH'ın KVC operasyonlarında ciddi risk faktörleri olduğunu, bu hastalarda ameliya öncesi alınacak idrar-trakeal kültürlerin postoperatuvar dönemde infeksiyon sorunu yaşayan hastalarda koruyucu ve yol gösterici olduğuna inanmaktayız.

Anahtar kelimeler: kardiyovasküler cerrahi, infeksiyon, kolonizasyon

\section{ABSTRACT}

Objective: Prevention of postoperative infections in cardiovascular surgery is possible with the treatment of preoperative infections. However, there is no routine clinical protocols agreed on patients without clinical complaints with normal laboratory findings but culture positive cultures and lower respiratory or urinary tract colonizations In our study we examined the clinical implication of asymptomatic patients with normal laboratory findings and colonization in their preoperative tracheal/urine cultures. Hence we aimed to identify major risk groups and share possible clinical results.

Method: Tracheal / urine cultures were obtained preoperatively from the CVS patients who had norma examination and laboratory findings between January 2016 - and June 2019 in our hospital. The patients were retrospectively divided into two groups as those having non reproductive (GI) and reproductive (G-II) cultures, and were compared in terms of demographic data, risk factors, cross-clamping/bypass times, intensive care/hospital stay, blood product consumption, major complications, systemic infection and mortality.

Results: Bacterial growth was found in 90 of 307 (61.1\%) patients with normal findings. Most frequently in trachea, Pseudomonas spp., and in urine E.coli were grown. Colonization was found significantly higher in female gender. There was no difference between the groups in terms of DM, HT, creatinine, albumin, EF and PAP values while there was significant difference between smokers and COPD patients. Also, it was found that G-II patients had longer ICU/hospital stay, more frequently required blood products and developed a higher rate of postoperative infection. There was no statistical difference between groups in terms of mortality.

Conclusion: We believe that smoking and COPD are serious risk factors in CVS operations, and tracheal) urine culture samples taken during preoperative period may be the guiding reference to high risk cardiovascular patients such as smokers and COPD who may suffer from postoperative infection.
Received/Geliș: 15.05 .2020

Accepted/Kabul: 12.08 .2020

Published Online/Online yayın: 21.09.2020

Nurşen Tanrıkulu

Şişli Meslek Yüksek Okulu, Anesteziyoloji Bölümü, Kolan International Hastanesi Kardiyovasküler Cerrahi Kliniği,

Anestezi Bölümü

İstanbul, Türkiye

nursentanrikulu1@gmail.com ORCiD: 0000-0003-3601-1468

A. Haspolat 0000-0003-2787-5889

Şişli Meslek Yüksek Okulu, Anesteziyoloji Bölümü, Kolan International Hastanesi Anesteziyoloji ve Yoğun Bakım Kliniği, istanbul, Türkiye

A. Ş. Köprülü 0000-0003-1392-8855 Yeni Yüzyıl Üniversitesi Tıp Fakültesi, Anesteziyoloji Reanimasyon Anabilim Dalı, istanbul, Türkiye

E. Demirsoy 0000-0002-7004-4530 Kolan International Hastanesi Kardiyovasküler Cerrahi Kliniği, istanbul, Türkiye

Keywords: cardiovascular surgery, infection, colonization

(C) Telif hakkı Göğüs Kalp Damar Anestezi ve Yoğun Bakım Derneği'ne aittir. Logos Tıp Yayıncılık tarafindan yayınlanmaktadır Bu dergide yayınlanan bütün makaleler Creative Commons Atff-Gayri Ticari 4.0 Uluslararası Lisansı ile lisanslanmıştır. 


\section{Giriş}

Açık kalp cerrahisi kardiyopulmoner baypas dolaşımı kullanımı nedeniyle ameliyat sırasında ve sonrasında yaşamsal organlarda yaygın patofizyolojik değişikliklere neden olan en önemli operasyonlardan biridir. Perioperatif dönemde fizyolojik, mekanik ve biyokimyasal büyük boyuttaki değişiklikler anesteziyolog ve kalp cerrahından oluşan cerrahi ekibin ameliyat öncesi kapsamlı bir değerlendirme yapmasını gerektirir $^{[1]}$

Antibiyotiklere karşı gelişen direncin giderek arttığ günümüzde kardiyovasküler cerrahi uygulanan hastalar arasında postoperatif infeksiyonlar ciddi mortalite morbidite nedeni olarak karşımıza çıkmaktadır. Yoğun ve çeşitli antibiyotik kullanım gereksinimi, uzamış yoğun bakım ve hastane kalış süreleri mortalite-morbiditede artışın yanı sıra maliyetleri de arttıran faktörler arasında önemli bir yer tutar ${ }^{[2]}$.

Postoperatif dönemde karşımıza çıkan infeksiyonların gelişimi için farklı risk faktörleri tanımlanmıştır. Kardiyovasküler cerrahide postoperatif infeksiyonların önlenebilmesi, preoperatif infeksiyonların doğru ve etkili tanı ve tedavisiyle olasıdır ${ }^{[3]}$. Ancak klinik yakınması olmayan, tüm laboratuvar bulguları normal olan fakat alt solunum yolu veya üriner sistem kolonizasyonu olan (kültür pozitif, infeksiyon bulguları negatif) hastalar üzerinde henüz düşünce birliğine varılmış ortak bir klinik protokol mevcut değildir. Ayrıca kolonizasyon ile infeksiyon arasındaki somut ilişki de henüz net olarak ortaya konamamıştır.

Biz de bu çalışmamızda, açık kalp cerrahisi uygulanan hastalarda kolonizasyonla postoperatif infeksiyon ilişkisini ortaya koymak ve olası risk gruplarını da tanımlayarak hastaların prognozuna olumlu katkı sağlamayı hedefledik.

\section{GEREÇ ve YÖNTEM}

Çalışmamıza hastanemiz kardiyovasküler cerrahi kliniğinde Ocak 2016 - Haziran 2019 tarihleri arasında elektif koşullarda açık kalp cerrahisi geçiren (izole iki ve/veya daha fazla damar koroner baypas greft KABG) ve ameliyat öncesi fizik muayene bulguları, lökosit sayısı, c reaktif protein (CRP) değeri normal sınırlarda olan hastalar dâhil edildi. Yatış/ameliyat onamlarında tıbbi verilerinin isim belli olmaksızın akademik amaçlarla kullanılabileceğine dair hasta onamı olanların klinik verileri hastane akademik kurulundan alınan izin sonrasında elektronik veri tabanından retrospektif olarak tarandı.

Çalışmamızda, kolonizasyon tanımı için; herhangi bir klinik ya da biyokimyasal infeksiyon bulgusu olmaksızın, hastaların alınan endotrakeal ve/veya idrar kültürlerinde mikroorganizmaların üremesi kabul edildi. Postoperatif infeksiyon tanımı içinse; patojen mikroorganizma veya toksinleri tarafından oluşturulan sistemik infeksiyon tanımı geçerli sayıldı ${ }^{[4-6]}$. Alınan örneklerde, trakeal aspirat örneğinin 3 farklı besiyerine (Gram (-) hedeflenerek Mac Concey, Gram (+) hedeflenerek kanlı agar ve mantar/maya hedeflenerek Sabouraud besi yeri), idrar örneğinin ise 2 faklı besiyerine (Gram (-) hedeflenerek Mac Concey, Gram (+) hedeflenerek kanlı agar besiyeri) ekilerek üretildiği, duyarlılık amacıyla da antibiyotik disk difüzyon yöntemi kullanıldığı mikrobiyoloji laboratuvarından öğrenildi.

Söz konusu tarihler arasında iki damar ve üzeri izole KABG ameliyatı geçirenler çalışma grubu olarak seçildi. Ancak, acil koşullarda ameliyata alınanlar, son iki aylık dönemde akut miyokart enfarktüsü geçirenler, hastanemizde veya başka bir sağlık kurumunda kardiyak ya da başka bir endikasyonla son iki aylık dönemde yatış öyküsü olanlar, ameliyat öncesi rutin fizik muayene bulgularında ve radyolojik/biyokimya tetkiklerinde infeksiyon lehine patoloji saptananlar çalışma kapsamı dışında bırakıldı.

Kliniğimizde uygulanan anestezi protokolü gereği hastalar ameliyattan en az 1 gün önce hospitalize edilerek ayrıntılı fizik muayaneleri ve biyokimyasal/ radyolojik tetkikleri yapılmaktadır. Bu tetkikler sonrasında ameliyata uygun kabul edilen hastalarda anes- 
tezi indüksiyonunda hastanın klinik özelliklerine göre intravenöz midazolam $(0.05-0.15 \mathrm{mg} / \mathrm{kg})$ ve/veya propofol $(1,5-2 \mathrm{mg} / \mathrm{kg} / \mathrm{dk})$ tercih edilir. İamede de aynı ilaçların (midazolam 0.03-0.1 mg/kg/saat, propofol 0.3-0.4 mg/kg/saat) devamlı infüzyonu ile birlikte opioid (fentanil 2-20 $\mathrm{\mu g} / \mathrm{kg} / \mathrm{saat}$ veya remifentanil $0.25-0,5 \mu \mathrm{g} / \mathrm{kg} / \mathrm{dk}$ ) kullanılır. Kas gevşetici olarak rokuronyum (indüksiyon $0.6 \mathrm{mg} / \mathrm{kg}$, idame $0.3-0.4$ $\mathrm{mg} / \mathrm{kg} / \mathrm{saat}$ ) uygulanmaktadır ${ }^{[7]}$. Hastaların tamamı orotrakeal entübe edildikten sonra rutin olarak steril koşullarda Lukens kabıyla trakeal kültür, idrar sondası uygulanmasını takiben de idrar kültürü alınır. Daha sonra da kalp cerrahisi anestezi sırasında standart olan, monitörizasyon yöntemleri kullanılarak ameliyata geçilir. Kliniğimizde izole KABG hastalarında normotermik yöntem tercih edilmektedir. Hastalara, kliniğimizce kabul edilmiş cerrahi antibiyotik profilaksisi gereğince sefazolin sodyum $2 \mathrm{~g}$ intravenöz (iv) damar yolunun açılmasını takiben (ortalama insizyondan $60 \mathrm{dk}$. önce) uygulanmaktadır. İlk dozu takiben, ameliyat başladıktan sonra 4. saatte $2 \mathrm{~g}$ iv ilave doz yapılır. Erken postoperatif dönemde ilk 48 saat her 8 saatte bir $2 \mathrm{gr}$ iv sefazolin sodyum tedavisine devam edilmektedir. Postoperatif dönemde vital ve biyokimyasal parametreler (hemogram, üre ve kreatinin, karaciğer fonksiyon testleri, CRP) takip edilir ve hastalar arasında infeksiyon açısından şüpheli görülenler; yoğun bakım ve infeksiyon hastalıkları uzmanı tarafından birlikte değerlendirilir. Eğer infeksiyon lehine bulgu saptanırsa kültürler tekrarlanır. Ancak, hastada ameliyatın öncesi alınan kültürlerde üreme varsa yeni kültür sonuçları beklenmeksizin o ajana yönelik antibiyogram duyarlılık sonuçlarına uygun antibiyotik değişikliği yapılır. Yeni kültür üremeleri görüldükten sonra eğer farklılık varsa tedavi yine gözden geçirilir.

Çalışmamızda, ön koşullara uyan hastalar anestezi indüksiyonu sonrası endotrakeal entubasyon ve idrar sondası uygulanmasını takiben alınan trakeal/idrar kültür sonuçlarına göre kültür negatif (Grup I - G I) ve kültür pozitif (Grup II - G II) hastalar olarak 2 gruba ayrıldı. Gruplar demografik özellikler (cinsiyet, yaş, kilo, boy), ameliyat öncesi hemotokrit, albümin ve kreatinin değerleri, ameliyat sırasındaki kros klemp ve pompa süreleri, komorbiditeler (Diabetes mellitus, hipertansiyon, karotis ve periferik arter hastalığı, kronik böbrek yetmezliği, sigara kullanımı, KOAH), ameliyat sonrası kan ürünleri (eritrosit süspansiyonu, taze donmuş plazma - TDP) kullanımı, atriyal fibrilasyon, postoperatuvar sistemik belirti veren infeksiyon oranı, majör diğer komplikasyonlar ve mortalite açısından karşılaştırılarak irdelendi.

\section{İstatistik}

İstatistiki analizler SPSS 24.0 (Chicago, IL, ABD) programı kullanılarak yapıldı. Frekans ve tanımlayıcı analizler dışında kategorik değişkenlerin karşılaştırılmasında ki-kare analizi, gruplar arasındaki farklııkların saptanmasında ise 2 grup olduğundan bağımsız örneklem t-testi seçildi. $p<0.05$ istatistiki anlamlı kabul edildi.

\section{BULGULAR}

Saptanan tarihler arasında iki damar ve üzeri izole KABG ameliyatı geçiren yaklaşık 500 hastanın dosyalarının gözden geçirilmesi sonucunda 307 hastanın çalışmanın tüm koşullarını karşıladığı saptandı. Hastalar çalışma metodolojisi gereğince üreme olup, olmamasına göre Grup I (kültürleri steril çıkanlar - $\mathrm{n}$ 217/\%70.68) ve Grup II (kolonize olanlar - n 90 / \%29.32) 2 farklı gruba bölündü. Her 2 grubun demografik bulgularının karşılaştırılmasında; yaş, kilo, boy arasında fark saptanmazken, G I'de kadın cinsiyet \%24.42 (n 53/217), G II'de ise kadın cinsiyet \%36.66 (33/90) oranında saptandı. Fark G II lehine istatistiki anlamlı yüksekti $(p=0.044 / p<0.05)$. Her 2 grubun demografik özellikleri Tablo 1'de özetlenmiştir.

Preoperatuvar dönemde kolonizasyon saptanan 90 hastalık gruptan 55 hastada (\%61.11) üremenin trakeada, 32 hastada idrarda (\%35.55), 3 hasta da ise hem trakeada hem de idrarda (\%3.33) olduğu görüldü. Trakeada en sık ilk 3 patojen Pseudomonas aeruginosa $(n=35, \% 62.50)$, Klebsiella $(n=7, \% 12.50)$, Candida ( $\mathrm{n}=5, \% 8.93$ ) olarak saptanırken, idrarda ise Escherichia coli ( $\mathrm{n}=13, \% 35.13)$, Klebsiella $(\mathrm{n}=7$, 
Tablo 1. Demografik bulgular.

\begin{tabular}{lcccc} 
& G I & G II & X veya t & p \\
\hline Hasta sayısı & 217 & 90 & - & \\
Cinsiyet (K/E-\%K) & $53 / 164-\% 24.42$ & $33 / 57-\% 36.66^{*}$ & $X^{2}=4.941$ & $0.044^{*}$ \\
Kilo (kg) & $80.51 \pm 13.02$ & $80.87 \pm 12.68$ & $\mathrm{t}=-0.221$ & 0.825 \\
Boy (cm) & $166.87 \pm 9.19$ & $165.41 \pm 8.10$ & $\mathrm{t}=1.302$ & 0.194 \\
Yaş (yıl) & $60.47 \pm 10.61$ & $62.65 \pm 10.31$ & $\mathrm{t}=-1.648$ & 0.100 \\
\hline
\end{tabular}

$K$ - Kadın, E-Erkek, $X^{2}=$ ki-kare analizi; $t=$ bağımsız örneklem $t$-testi

(*) p<0.05: istatistiki anlamlı fark

Tablo 2. Trakea ve idrar kültüründe üreyen patojen mikroorganizmalar.

\begin{tabular}{lclc}
\multicolumn{2}{c}{ Trakea } & \multicolumn{2}{c}{ Idrar } \\
\hline Pseudomonas spp. & $35-\% 62$ & E. coli & $13-\% 35.13$ \\
Klebsiella & $7-\% 12.50$ & Klebsiella & $7-\% 18.92$ \\
Candida & $5-\% 8.93$ & Enterobakter & $5-\% 13.51$ \\
MRSE & $2-\% 3.57$ & Candida & $3-\% 8.11$ \\
Enterobakter & $2-\% 3.57$ & Streptohomonas & $2-\% 5.41$ \\
Micrococcus & $2-\% 3.57$ & MRSE & $2-\% 5.41$ \\
Acinetabakter & $1-\% 1.78$ & Enteroccus fecalis $2-\% 5.41$ \\
Pantoea & $1-\% 1.78$ & Pseudomonas & $1-\% 2.70$ \\
& 56 & MRSA & $1-\% 2.70$ \\
& & Citrobakter & $1-\% 2.70$ \\
& & & $\mathbf{3 7}$
\end{tabular}

\%18.92), enterobakter ( $n=5, \% 13.51$ ) üretildi. Üreme yerleri ve patojenler Tablo 2 'de listelenmiştir.

Grupların ameliyat öncesi önem taşıyan laboratuvar değişkenleri (hematokrit, albümin, kreatinin) ve komorbiditeleri (sigara kullanımı, diyabet, hipertansiyon, periferik-karotis arter hastalığı, diyaliz gereksinimi olmayan kronik böbrek yetmezliği, KOAH, ejeksiyon fraksiyonu, pulmoner arter basıncı) arasındaki yapılan karşılaştırmada kolonize hastalarda (G II) sigara kullanımının $(p=0.006 / p<0.05), K^{\prime} O A H^{\prime} ı n$ $(p=0.016 / p<0.05)$ istatistiki anlamlı daha sık görüldüğü diğerlerinde ise farklılık olmadığı saptandı. Tüm veriler Tablo 3'te paylaşılmıştır.

Ameliyat süresince postoperatuvar dönemde hastanın prognozunda belirleyici olabilecek faktörlerden olan kros klemp (G I - 66.66 29.46 , G II - 67.08 28.76 dk.) ve baypas pompa sürelerinde ( $\mathrm{I}-108.32 \pm 39.78$, G II - 107.98 \pm 42.23 dk.) gruplar arasında istatistiki anlamlı farklılık saptanmadı.
Ameliyat sonrası dönem için yapılan değerlendirmede, hastaların YBÜ yatış (G I-2.29 22.27, G II-3,65 \pm 2.75 gün- $p=0.03 / p<0.05$ ) ve hastanede yatış sürelerinin ( $G$ I - 8.11 2 2.91, G II - 10.31 \pm 5.62 gün - $p=0.001 / p<0.05$ ) G II lehine istatistiki anlamlı daha uzun olduğu görüldü. G II'de tüm tedavi süresi içerisinde daha fazla kan ürünü kullanıldığı (eritrosit süspansiyonu $G$ I-3.09 \pm 2.64 , G II-3.98 \pm 3.39 ünite- $p=0.001 /$ TDP G । $-1.45 \pm 1.06$, G II-2.55 \pm 1.52 ünite- $p=0.001$ ) saptandı. Kolonize grupta postoperatif dönemde daha yüksek oranda majör komplikasyon (G I - \%1.38, G II - \%7.78) geliştiği de görüldü $(p=0.004 / p<0.05)$. Bu komplikasyonlar G I'de (n 3) tam blok (1), ciddi aritmi (1), uzun süreli plevral efüzyon (1), G II'de (n 7) ise uzun süreli plevral efüzyon (3), ciddi aritmi (2), geçici iskemik atak (1), ileus (1) olarak not edildi. Postoperatuvar atriyal fibrilasyon oran olarak G II'de yüksek olmasına karşın istatistiki fark anlamlı değildi ( $p=0.375 / p>0.05)$.

Çalışmaya kabul edilen 307 hastanın toplam 21 'inde (\%6.84) postoperatuvar infeksiyon not edildi. G I'de sternum insizyonu (2), safen insizyonu (2), mediasten (1), pnömoni (1), santral venöz katater (1), idrar yolu infeksiyonu (1) olmak üzere postoperatif sistemik infeksiyon 8 hastada (\%3.68) saptandı. G II'de ise sternum insizyonu (3), safen insizyonu (3), idrar yolu infeksiyonu (3), mediasten (2), pnömoni (2) toplam 13 hastada (\%14.44) görüldü. Fark G II lehine ileri derecede anlamlıydı $(p=0.001 / p<0.05)$.

Çalışmaya dâhil edilen 307 hastanın 5'i $(\% 1,63)$ erken postoperatif dönem içinde kaybedildi. Kaybedilen 3 hasta G I'de (\%1.38), 2 hasta G II'de (\%2.22) yer almaktaydı. G I'de 1 hasta postoperatif erken dönem- 
Tablo 3. Komorbiditelerin ve pre/peroperatuvar majör belirteçlerin karşılaştırılması.

\begin{tabular}{lcccc} 
& G I (n 217) & G II (n 90) & $\mathbf{X}^{2}, \mathbf{t} /$ & $\mathbf{p}$ \\
\hline Sigara & $37-\% 17.05$ & $28-\% 31.11$ & $X^{2}=7.535$ & $0.006^{*}$ \\
Diyabet & $101-\% 46.54$ & $44-\% 48.88$ & $X^{2}=0.140$ & 0.708 \\
Hipertansiyon & $122-\% 56.22$ & $55-\% 61.11$ & $X^{2}=0.623$ & 0.430 \\
Perf./Kar. Arter Hastalığı & $23-\% 10.59$ & $15-\% 16.66$ & $X^{2}=1.944$ & 0.163 \\
KBY (diyaliz yapılmayan) & $9-\% 4.14$ & $5-\% 5.55$ & $X^{2}=2.948$ & 0.077 \\
KOAH & $25-\% 11.52$ & $20-\% 22.22$ & $X^{2}=5.824$ & $0.016 *$ \\
Ejeksiyon fraksiyonu & $53.41 \pm 8.99$ & $50.42 \pm 10.18$ & $\mathrm{t}=1.538$ & 0.124 \\
Pulmoner arter basıncl & $28.03 \pm 10.55$ & $31.93 \pm 14.63$ & $\mathrm{t}=-1.608$ & 0.214 \\
Preoperatif hematokrit & $36.46 \pm 6.75$ & $38.54 \pm 5.59$ & $\mathrm{t}=1.605$ & 0.271 \\
Preoperatif albümin & $3.97 \pm 0.54$ & $3.79 \pm 0.67$ & $\mathrm{t}=1.329$ & 0.117 \\
Preoperatif kreatinin & $0.93 \pm 0.44$ & $1.01 \pm 0.56$ & $\mathrm{t}=-1.534$ & 0.126 \\
\hline
\end{tabular}

Perf.: periferik, Kar.: karotis, KBY: kronik böbrek yetmezliği, KOAH: kronik obstuktif akciğer hastalığı, $X^{2}=$ ki-kare analizi; $t=$ bağımsız örneklem $t$-testi

(*) p<0.05; istatistiki anlamlı fark

de gelişen miyokard infarktüsü nedeniyle diğer 1 hasta ise geç postoperatif dönemde gelişen böbrek yetmezliği nedeniyle ameliyat sonrası 2 . ay dış merkezde kaybedildi. Üçüncü hasta ise postoperatif 20. gün gelişen mediastinal infeksiyon nedeniyle eksitus oldu. G II'de iki hasta da mediastinal infeksiyona bağlı gelişen sepsis nedeniyle kaybedildi. Bu hastalardan 1 'inde preoperatif idrar kültüründe metisilin dirençli Staphylococcus epidermidis (MRSE) kolonizasyonu varken postoperatif 3 . gün yine alınan idrar kültüründe Klebsiella oxytoca üremesi saptandı. Postoperatif 10. gün sternal insizyonda başlayan akıntı ile beraber yapılan toraks tomografisinde mediastinal infeksiyon belirlendi. Bu sırada alınan trakea ve sternum akıntı kültürlerinde de Klebsiella oxytoca üredi. Kültür anti- biyograma yönelik kombine yoğun antibiyotik ve diğer destek tedaviye karşın postoperatif 25. gün sepsis nedeniyle kaybedildi. Diğer eksitus olan hastanın da preop ve postop trakeal kültüründe Pseudomonas auriginosa üredi. Aynı patojen postoperatuvar 9. günde mediastende de üretildi. Hasta yaklaşık 3 haftalık tedavi süreci sonrasında sepsis tablosunda eksitus oldu. Özetle ameliyat sonrası yoğun bakım ve hastane yatış sürelerinde, eritrosit süspansiyonu ve TDP kullanımında, postoperatuvar sistemik infeksiyon, diğer majör komplikasyonlarda kolonize grup lehine istatistiki anlamlı farklılık görüldü. Mortalite ise GII'de oransal olarak yüksek olmasına karşın fark istatistiki anlamlı değildi. Bulgular Tablo 4'te özetlenmiştir.

Tablo 4. Her 2 grubun sonuç parametrelerinin karşılaştırılması.

\begin{tabular}{lcccc} 
& G I (n 217) & G II (n 90) & X, $\mathbf{t}$ & $\mathbf{p}$ \\
\hline Kros klemp süresi & $66.66 \pm 29.46$ & $67.08 \pm 28.76$ & $\mathrm{t}=-0.116$ & 0.908 \\
Baypas pompa süresi & $108.32 \pm 39.78$ & $107.98 \pm 42.23$ & $\mathrm{t}=0.065$ & 0.949 \\
YBU yatış süresi & $2.29 \pm 2.27$ & $3.65 \pm 2.75$ & $\mathrm{t}=-3.004$ & $0.030^{*}$ \\
Hastanede yatış süresi & $8.11 \pm 2.91$ & $10.31 \pm 5.62$ & $\mathrm{t}=-4.472$ & $0.001^{*}$ \\
Eritrosit susp. kullanımı & $3.09 \pm 2.64$ & $3.98 \pm 3.39$ & $\mathrm{t}=-3.365$ & $0.001^{*}$ \\
TDP kullanımı & $1.45 \pm 1.06$ & $2.55 \pm 1.52$ & $\mathrm{t}=-3.365$ & $0.001^{*}$ \\
Postoperatuvar AF & $61-\% 28.11$ & $30-\% 33.33$ & $\mathrm{X}^{2}=0.789$ & 0.375 \\
Postop. sistemik infek. & $8-\% 3.68$ & $13-\% 14.44$ & $\mathrm{X}^{2}=11.553$ & $0.001^{*}$ \\
Diğer majör komp. & $3-\% 1.38$ & $7-\% 7.78$ & $\mathrm{X}^{2}=8.257$ & $0.004^{*}$ \\
Mortalite (eksitus - \%) & $3-\% 1.38$ & $2-\% 2.22$ & $\mathrm{X}^{2}=0.280$ & 0.597 \\
\hline
\end{tabular}

${ }^{*} p<0.05 ; X^{2}=k i$-kare analizi; $t=$ bağımsız örneklem $t$-testi 


\section{TARTIŞMA}

Çalışmamızın sonucunda kadınlarda, sigara içenlerde ve KOAH'lı hastalarda kolonizasyonun daha sık rastlanabileceğini saptadık. Daha da önemlisi kolonize hastalarda postoperatif sistemik infeksiyonun, diğer major komplikasyonların daha yüksek oranda görüldüğünü gözlemledik. Ek olarak da bu hastalarda kan ve kan ürünü kullanımının daha fazla ve yoğun bakım / hastane yatış sürelerinin daha uzun olduğunu gördük. Mortalite oranı ise kolonize grupta yüzdelik değer olarak daha yüksek olmasına karşın 2 grup arasındaki fark istastiki anlamlı değildi.

Çalışmamızın demografik bulguları irdelendiğinde, kadın cinsiyette kolonizasyon daha sık saptanmıştır. Uzunca zamandır kadınların KABG ameliyatından sonra erkeklerden daha yüksek operatif mortaliteye sahip olduğu söylenmektedir [8,9]. 2005 yılında, Blankstein ve ark. ${ }^{[9]} 31$ hastanede, 15.440 hastada elde ettiği veriler ışığında KABG geçiren kadınların erkeklere oranla daha fazla komorbiditeye sahip olduklarını göstermişler ve kadınlardaki yüksek CABG mortalitesinin çoğunluğunu komorbidite sıklığındaki artışla açıklamışlardır. Bununla birlikte, aynı çalışmada düşük vücut kitle indeksi dahil tüm tanımlanabilir risk faktörleri ayıklandıktan sonra bile kadın cinsiyetinin perioperatif ölüm oranında bağımsız bir risk faktörü olduğu saptanmıştır. 2010 yılında Bukkapatnam 121 hastanede 10.708 kadın 29.669 erkek izole KABG operasyonu geçiren hastada yaptığı çalışmada kadınlarda gözlenen mortalite erkeklere göre anlamlı derecede yüksek bulmuştur (\% 4.60 karşın \% 2.53). Erkeklerin 3'ten fazla koroner arter lezyonuna sahip olması ve sol ventrikül disfonksiyonu prevalansı daha yüksek olmasına karşın, kadınların daha yaşlı, diyabetik olma, evre 3-5 kronik böbrek hastalığı, kronik akciğer hastalığı olma olasılığının daha yüksek olduğu saptanmıştır. Sonuçta, ABD devleti tarafından sağlanan büyük veri havuzunda preoperatif risk faktörlerinin etkisinin giderilmesine karşın, kadınların izole KABG'den sonra erkeklere oranla daha yüksek mortalite riski altında olduğu gösterilmiştir ${ }^{[8]}$. Son yıllarda Nicolini gibi bazı araştırmacılar bunun aksini de iddia etseler de ${ }^{[10]}$ genelde hâlen kadın cinsiyet komorbiditelerden bağımsız tek başına risk faktörü olarak kabul edilmektedir. Bizim de hasta serimizde benzer bir cinsiyet farklılığı saptanmış olup, bunun menopoz öncesi dönemde hormonlardan ve diğer tüm yaş grupları içinde anatomik bazı farklı özelliklerden kaynaklanabileceğini düşünmekteyiz ${ }^{[11]}$.

Kolonize grupta hipertansiyon ve periferik/karotis arter hastaları sayısal/oransal olarak yüksek olsa bile fark istatistiki anlamlı bulunmamıştır. Sonuçta, her 2 gruptaki hastaların koroner hastası olduğu hesaba katılırsa bulgular şaşırtıcı değildir.

Kadın cinsiyete ek olarak sigara içenlerde ve KOAH'ılarda kolonizasyon anlamlı olarak yüksek oranda saptanmıştır. Normal akciğer fonksiyonuna sahip bireyler, üst solunum yollarındaki asemptomatik kolonize normal mikrobiyota ile alt solunum yollarındaki steril ortam arasında belli bir dengeyi korur. Bu koruyucu denge sigara içmek gibi bir dış etkenle bozulabilir. Sigara ve sigara ile ilişkili hastalıkların yüksek infeksiyon riski ile ilişkili olduğu bilinmektedir. Solunum sisteminde, inhale sigara dumanının karmaşık ve zararlı etkileri konakçı - mikroorganizma etkileşim dinamiklerini tüm anatomik seviyelerde değiştirerek birçok hastada infeksiyona neden olur ${ }^{[12]}$.

Dahası, sigara dumanına sürekli maruz kalma kronik obstrüktif akciğer hastalığı (KOAH) gibi kronik solunum yolu hastalıklarının gelişimini de tetikler. $\mathrm{KOAH}$ hava yollarının amfizem, fibrozis, mukus hipersekresyonu ve alt solunum yollarının kalıcı fırsatçı patojenlerle kolonizasyonuyla birlikte oluşan geri dönüşümsüz bir hava akımı tıkanıklığıdır. Sigara dumanının konak-patojen etkileşimi üzerine etkisi, kronik inflamatuar süreçlerin ve kalıcı kolonizörlerin varlığı solunum sistemindeki dinamikleri olumsuz etkilediği bilinmektedir ${ }^{[12]}$. Akciğerdeki yapısal ve inflamatuar hücreler sigara dumanı maruziyeti sonrası proenflamatuar mediatörler serbestliyerek kronik bir inflamasyon oluşmasına katkıda bulunan yeni ek inflamatuvar hücreler oluştururlar. Kronik inflamasyon akciğere zarar verir, doğuştan gelen ve sonradan kazanı- 
lan immun yanıtı kötü etkiler ve yineleyen solunum yolu infeksiyonu ataklarını kolaylaştırır ${ }^{[13]}$. Bağışıklık sistemindeki fonksiyon bozuklukları alevlenmelere ve hastalığın ilerlemesine neden olur. Farelerde oluşturulan KOAH'da sigara dumanının etkisiyle regulatör ve effektör $T$ hücrelerinin varlığının ve fonksiyonun derinden etkilendiği ve immun yanıtın baskılandığı gösterilmiştir ${ }^{[13]}$. KOAH'lı bireylerde solunum yolu infeksiyonlarına karşı artan duyarlılık vardır ve aktif infeksiyon atakları da hastalığın alevlenmesine neden olur. Giderek artan kanıtlar, hava yolu epitel bariyeri ve alveolar makrofajlar, nötrofiller, dendritik hücreler ve doğal öldürücü hücreler de dâhil olmak üzere doğuştan gelen bağışıklık hücreleri tarafından sağlananlar gibi çoklu konakçı savunma mekanizmalarının sigaraya bağımlı bir şekilde geniş ölçüde bastırıldığını göstermektedir ${ }^{[14]}$. Kusurlu bağışıklık savunmasının bir sonucu olarak, KOAH-sigara içenlerin akciğerleri sıklıkla patojenlerle kolonize edilir ve genellikle hastalık ilerlemesinin ana itici gücü olan ikincil iltihaplanmaya neden olan bakteriyel ve viral infeksiyonlar gelişir ${ }^{[14]}$.

Çalışma grubumuzda, postoperatuvar infekiyon oranı \%6.84 saptanmış olup, diğer merkezlerle karşılaştırıldığında oldukça düşük görünmektedir. Literatürde çok farklı oranlar bildirilmiş olmakla birlikte, 2006 yılında 13 Avrupa ülkesi ve 42 hastaneyi kapsayan çalışmada \%26.8 olarak bildirilmiştir. Merkezimize benzeyen daha az sayıda ameliyat yapılan bir merkezdeki diğer bir çalışmada, oran \%13.95 bulunmuştur ${ }^{[2]}$. Oranımız düşük olarak bildirilen oranın bile ancak yarısı kadardır. Bunda deneyimli ekiplerimiz ve özenli bakımımızın yanı sıra seçtiğimiz çalışma grubunun da (elektif, izole KABG vb.) ve normotermik yöntemi tercih etmemizin de etkin rol oynadığını düşünüyoruz.

Kardiyovasküler cerrahi antibiyotik profilaksisi yapılması gereken majör cerrahilerin en başında yer almaktadır. Profilaksi amacıyla antibiyotik uygulanma zamanı, süresi, kullanılacak antibiyotik konusunda geçmişte tam düşünce birliği mevcut değilse de günümüzde genel olarak antibiyotik uygulaması için en uygun zamanın cerrahi insizyondan 30-60 dk. önce (yaklaşık olarak anestezi indüksiyonu) ve süresinin de 48 saatle sınırlı olduğu düşünülmektedir ${ }^{[15]}$. Biz de kliniğimizde profilaksi amacıyla bu prensipleri uygulamaktayız. Bu uygulamamızın da diğer faktörlerin yanı sıra düşük infeksiyon oranına olumlu katkıda bulunduğuna inanıyoruz.

Kolonize hastalarla ilgili, özellikle asemptomatik bakteriürilere uygulanması gereken tedavi protokolleri üzerinden somutlaşan iki karşıt fikir vardır. Bunlardan birincisi Soltanzadeh ve ark. ${ }^{[1]}$ savunduğu ekstrakorporeal dolaşımın vücudun bağışıklık sistemini baskıladığından hareketle asemptomatik kolonizasyonların aktif infeksiyona dönüşebileceği olasığıdır. Bu yazarlara göre bakterilerin hematojen yayılımı ürosepsis, sepsis, mediastinit ve eğer kapak vb. yerleşimi kolaylaştırıcı yabancı bir materyal kullanıldıysa endokardite neden olabilirler. Bu nedenle benzer düşünen yazarlar kolonizasyonların preoperatuvar dönemde tedavi edilmesini öneririler ${ }^{[1,16-19]}$. Bunun karşıt teorisi ise Darouiche ve ark. ${ }^{[20]}$ kolonizasyonun tedavi edilmesinin çok daha dirençli ve patojen ajanlarla infeksiyon oluşmasına neden olabileceği iddiasıdır. Drekonja ve ark. ${ }^{[20-23]}$ da yaptıkları bir çalışmada, asemptomatik bakteriürisi olan hastalarda (ortopedik, kardiyotorasik ve vasküler ameliyatlarda) yapılan preoperatif tedavinin çok daha yüksek oranda cerrahi alan infeksiyonuna neden olduğunu göstermiştir.

Pediatrik kalp cerrahisinde de kolonizasyon önemli bir tartışma konusudur. Ağılıklı olarak konjenital cerrahi yapılan merkezlere hastalar diğer hastanelerden sevk edilerek gelir. Bu hastaların önemli bir bölümü kardiyak cerrahi öncesi tetkik/tanı ve stabilizasyon aşamasında azımsanmayacak bir süre farklı hastanelerde yatarak tedavi görürler. Ek olarak bu hasta grubu içinde sosyoekonomik daha alt düzeylerdeki gelir gruplardan hatta geri kalmış ülkelerden gelenlerin sıklığı yüksektir. Bu da hastalarda farklı antibiyotiklere dirençli mikroorganizmaların kolonizasyonunu kolaylaştırır. Bazı yazarlar preoperatif burun-rektal kolonizasyonunun cerrahi alan infeksiyonlarında en önemli risk faktörü olduğunu savunurlarken [24,25], 
diğer bazı yazarlar bu bulguları onaylatamamışlardır ${ }^{[26-28]}$. Ben-Ami ${ }^{[29]}$ gibi yazarlar ise kolonizasyonun potensiyel risk faktörü olmadığını söylemiştir. Tüm bu nedenlerle özellikli bir hasta grubu olmasına karşın pediyatrik KVC hasta grubunda bile kolonizasyonun ameliyat öncesi rutin araştırılması halen bakımın standart uygulaması hâline gelmemiştir ${ }^{[27]}$.

Bu kadar karşıt düşüncelerin varlığı ve her birinin kendi düşüncelerini destekleyecek çalışmalar yapmış olması kafa karıştırıcı olup, bu konuda somut bir çıkarım yapmayı güçleştirmektedir. Biz kendi kliniğimizde nasıl her hastanenin kendi florası hakkındaki spesifik bilginin infeksiyon kontrolüne yardımcı olduğu genel kabul görmüş bir bilgiyse aynı koşulların her birey içinde geçerli olduğuna inanıyoruz. Kanımızca bir hastada kolonizasyonun saptanması o hastanın ameliyatının ertelenmesi için ya da saptanan mikoorganizmaya karşın duyarlı antibiyotik başlanması için yeterli değildir. Böyle rutin uygulamalar hem antibiyotik direncini arttırır hem de gereksiz ek ilaç maliyeti ve yan etki riski oluşturur. Kliniğimizde yaptığımız uygulamada, kolonize olduğunu saptadığımız hastalarda erken postoperatuvar dönemde infeksiyon lehine bulgu (ateş, yükselen lökosit, CRP - procalcitonin değerleri, alana özel klinik semptom) saptıyorsak antibiyotik değişiminde öncelikli olarak preoperatuvar saptanan kolonizasyon ajanlarına duyarlı olanları tercih ediyoruz. Böylece hem ampirik geniş spektrumlu antibiyotik kullanımın bilinen yan etkilerinden (dirençli patojen üremesi, kullanılan antibiyotiğe direnç gelişmesi, maliyet, yan etki riski) korunuyoruz hem de yeni kültür-antibiyogram sonuçlarının elde edilmesi için geçecek kritik süreden tasarruf ediyoruz. Bu hastalarda preoperatif dönemde alınacak idrar ve balgam kültürlerinin postoperatif dönemde infeksiyon gelişimi açısından sorun yaşayan hastalarda özellikle antibiyogram ile birlikte yol gösterici olduğuna inanıyoruz.

Bu çalışma bir "maliyet çalışması" değildir. Ancak, yoğun bakım ve hastane yatış sürelerinin uzaması, kan ürünlerinin daha sık kullanılması, komplikasyonların daha sık görülmesi, mortalitenin istatistiki anlamlı olmasa da sayısal olarak daha fazla olmasının maliyetlere de yansıması ve kolonize hastalara yapılacak harcamaların daha yüksek olması beklenir. Bu nedenle özellikle risk grubundaki sigara içen, $\mathrm{KOAH}^{\prime} \mathrm{I}$ hastalardan preoperatuvar dönemde steril koşullarda trakeal-idrar kültürü alınmasını, operasyon sonrası infeksiyon düşünülen hastalarda ampirik geniş spektrumlu antibiyotik uygulaması yerine bu kültür sonuçlarına göre antibiyotik seçimin yapılmasını öneriyoruz.

Her çalışmanın olduğu gibi bizim de çalışmamızın bazı kısıtıııkları vardır. Her şeyden önce çalışmamız tek merkezli, retrospektif olup geçmişte opere olan hastaların yatış dosyasındaki gözlemsel verilere dayanmaktadır. Ayrıca olgu bütünlüğü sağlanması açısından genel sağlık durumu stabil, elektif izole CABG ameliyatları seçilmiş olup infeksiyon sorunlarının daha yoğun yaşandığı, morbidite-mortalitenin daha yüksek olduğu her türlü acil girişimler, vasküler ameliyatlar, kapak replasmanları ya da reoperasyonlar bu çalışma kapsamı dışında bırakılmıştır. Ek olarak veriler hastaların yatış dosyalarından elde edildiğinden taburcu sonrası takip sırasında poliklinikte saptanan ve ayaktan tedavi edilen komplikasyonlara da ulaşılamamıştır. Konu infeksiyon olduğundan retrospektif koşullarda hastalar arası etkileşim de değerlendirilememiştir. Ayrıca çalışmaya kabul edilen hastaların hastanemiz öncesindeki yatış, geçmiş hastalıklarına ait bilgiler de kısıtlıdır. Çoğu hastanın son 2 aydan önceki sağlık verileri ancak dosyalara kaydedilen sınırlarda bilinmektedir. Ek olarak bu hastalardan ameliyat öncesi bazı kliniklerde rutin uygulanmaya başlayan nasal ve rektal sürüntü örnekleri alınmamıştır. Kanımızca preoperatif burun ve rektal kolonizasyonu da çalışmamıza dâhil edebilseydik belki de \%29.32 olan kolonize hasta oranı çok daha yüksek olacaktı. Ayrıca diğer çalışmaların çoğuna oranla çok daha iyi, tercih edilen bir yöntem olmasına karşın kültür almanın da kendi içinde sınırları vardır. Kültür yerine polimeraz zincir reaksiyonu (PCR) yapılabilmiş olsaydık muhtemelen çok daha gerçeğe uygun veriler saptanabilirdi. 
Sonuç olarak, postoperatif dönemde infeksiyon gelişen hastalarda preoperatuvar dönemdeki kültür sonuçlarının, özellikle antibiyotik değişikliği gereken hastalar açısından yol gösterici olduğuna inanıyoruz. Bu yaklaşımın özellikle sigara içicisi ve $\mathrm{KOAH}$ gibi risk grubu hastalarda yalnızca zamanlama açısından daha erken, duyarlı ve etkili antibiyoterapinin başlatılmasını sağlamakla kalmadığını aynı zamanda yoğun bakım/ hastanede kalış sürelerini kısalttığını, komplikasyonları azalttığını ve morbidite, mortalite ve maliyet üzerine de pozitif etkisinin olduğunu düşünüyoruz.

\section{KAYNAKLAR}

1. Soltanzadeh $M$, Ebadi $A$. Is presence of bacteria in preoperative microscopic urinalysis of the patients scheduled for cardiac surgery a reason for cancellation of elective operation? Anesth Pain Med. 2013 Spring; 2(4):174-7. https://doi.org/10.5812/aapm.8667

2. Lola I, Levidiotou S, Petrou A, Arnaoutoglou H, Apostolakis E, Papadopoulos GS. Are there independent predisposing factors for postoperative infections following open heart surgery? J Cardiothorac Surg. 2011 Nov 14; 6:151.

https://doi.org/10.1186/1749-8090-6-151

3. de Lange MP, Sonker U, Kelder JC, de Vos R. Practice variation in treatment of suspected asymptomatic bacteriuria prior to cardiac surgery: are there differences in postoperative outcome? A retrospective cohort study. Interact Cardiovasc Thorac Surg. 2016 Jun; 22(6):769-75.

https://doi.org/10.1093/icvts/ivw039

4. Silvetti S, Ranucci M, Isgrò G, Villa V, Costa E. Preoperative colonization in pediatric cardiac surgery and its impact on postoperative infections. Paediatr Anaesth. 2017 Aug; 27(8):849-55. https://doi.org/10.1111/pan.13169

5. Nicolle LE, Gupta K, Bradley SF, Colgan R, DeMuri GP, Drekonja $D$, et. al. Clinical practice guideline for the management of asymptomatic bacteriuria: 2019 Update by the infectious diseases Society of America. Clin Infect Dis. 2019 May 2; 68(10):e83-e110. https://doi.org/10.1093/cid/ciy1121

6. Nicolle LE. Asymptomatic bacteriuria: when to screen and when to treat. Infect Dis Clin North Am. 2003 Jun; 17(2):367-94.

https://doi.org/10.1016/S0891-5520(03)00008-4

7. London MJ, Mittnacht AJ, Kaplan JA. Anesthesia for myocardial revascularization p585. In Kaplan JA, Reich DL, Lake CL, Konstadt SN. Kaplan's cardiac anesthesia. Fifth edition. Saunders Elsevier, Philadelphia, USA 2006.

8. Bukkapatnam RN, Yeo KK, Li Z, Amsterdam EA.
Operative mortality in women and men undergoing coronary artery bypass grafting (from the California Coronary Artery Bypass Grafting Outcomes Reporting Program). Am J Cardiol. 2010 Feb 1; 105(3):339-42. https://doi.org/10.1016/j.amjcard.2009.09.035

9. Blankstein R, Ward RP, Arnsdorf M, Jones B, Lou YB, Pine $M$. Female gender is an independent predictor of operative mortality after coronary artery bypass graft surgery: contemporary analysis of 31 Midwestern hospitals. Circulation. 2005 Aug 30; 112(9 Suppl):1323-7. https://doi.org/10.1161/circulationaha.104.525139

10. Swaminathan RV, Feldman DN, Pashun RA, Patil RK, Shah T, Geleris JD, et. al. Gender differences in in-hospital outcomes after coronary artery bypass grafting. Am J Cardiol. 2016 Aug 1;118(3):362-8. https://doi.org/10.1016/j.amjcard.2016.05.004

11. Ingersoll MA. Sex differences shape the response to infectious diseases. PLoS Pathog. 2017 Dec 28;13(12): e1006688. https://doi.org/10.1371/journal.ppat.1006688

12. Garmendia J, Morey P, Bengoechea JA. Impact of cigarette smoke exposure on host-bacterial pathogen interactions. Eur Respir J. 2012 Feb; 39(2):467-77. https://doi.org/10.1183/09031936.00061911

13. Bhat TA, Panzica L, Kalathil SG, Thanavala Y. Immune dysfunction in patients with chronic obstructive pulmonary disease. Ann Am Thorac Soc. 2015 Nov; 12 Suppl 2:S169-75. https://doi.org/10.1513/AnnalsATS.201503-126AW.

14. Shaykhiev R, Crystal RG. Innate immunity and chronic obstructive pulmonary disease: a mini-review. Gerontology. 2013;59(6):481-9. https://doi.org/10.1159/000354173

15. Lador A, Nasir H, Mansur N, Sharoni E, Biderman P, Leibovici $L$, et. al. Antibiotic prophylaxis in cardiac surgery: systematic review and meta-analysis. J Antimicrob Chemother. 2012 Mar; 67(3):541-50. https://doi.org/10.1093/jac/dkr470q

16. Branger S, Casalta JP, Habib G, Collard F, Raoult D. Escherichia coli endocarditis: seven new cases in adults and review of the literature. Eur J Clin Microbiol Infect Dis. 2005;24:537-41. https://doi.org/10.1007/s10096-005-1379-6

17. Gould CV, Umscheid CA, Agarwal RK, Kuntz G, Pegues DA. Guideline for prevention of Catheter Associated urinary tract infections 2009. Infect Control Hosp Epidemiol. 2010;31:319-26. https://doi.org/10.1086/651091

18. Cordero-Ampuero J, Gonzalez-Fernandez E, MartinezVelez D, Esteban J. Are antibiotics necessary in hip arthroplasty with asymptomatic bacteriuria? Seeding risk with/without treatment. Clin Orthop Relat Res. 2013;471:3822-9. https://doi.org/10.1007/s11999-013-2868-z

19. Ollivere BJ, Ellahee N, Logan K, Miller-Jones JC, Allen $\mathrm{PW}$. Asymptomatic urinary tract colonisation predisposes to superficial wound infection in elective orthopaedic surgery. Int Orthop. 2009;33:847-50. 
https://doi.org/10.1007/s00264-008-0573-4

20. Darouiche RO, Hull RA. Bacterial interference for prevention of urinary tract infection. Clin Infect Dis. 2012;55:1400-7.

https://doi.org/10.1093/cid/cis639

21. Edlund C, Nord CE. Effect on the human normal microflora of oral antibiotics for treatment of urinary tract infections. J Antimicrob Chemother. 2000;46:41-8. https://doi.org/10.1093/jac/46.suppl_1.41

22. Cai T, Mazzoli S, Mondaini N, Meacci F, Nesi G, D'Elia C et al. The role of asymptomatic bacteriuria in young women with recurrent urinary tract infections: to treat or not to treat? Clin Infect Dis. 2012;55:771-7. https://doi.org/10.1093/cid/cis534

23. Drekonja DM, Zarmbinski B, Johnson JR. Preoperative urine cultures at a veterans affairs medical center. JAMA Intern Med. 2013;173:71-2. https://doi.org/10.1001/2013.jamainternmed.834

24. Katayanagi T. Nasal methicillin-resistant S. aureus is a major risk for mediastinitis in pediatric cardiac surgery. Ann Thorac Cardiovasc Surg. 2015;21(1):37-44. https://doi.org/10.5761/atcs.oa.14-00157

25. Ruef C1, Fanconi S, Nadal D. Sternal wound infection after heart operations in pediatric patients associated with nasal carriage of Staphylococcus aureus. J Thorac
Cardiovasc Surg. 1996 Sep; 112(3):681-6.

https://doi.org/10.5761/atcs.oa.14-00157

26. Jaworski R, Haponiuk I, Steffens M, Arlukowicz E, IrgaJaworska N, Chojnicki M, et. al. Colonization of multidrug resistant pathogens in a hybrid pediatric cardiac surgery center. Arch Med Sci. 2016 Jun 1;12(3):63944.

https://doi.org/10.5114/aoms.2016.59937

27. Woodward CS, Son M, Calhoon J, Michalek J, Husain SA. Sternal wound infections in pediatric congenital cardiac surgery: a survey of incidence and preventative practice. Ann Thorac Surg. 2011 Mar; 91(3):799-804. https://doi.org/10.1016/j.athoracsur.2010.10.030

28. Macher J, Gras Le Guen C, Chenouard A, Liet JM, Gaillard Le Roux B, Legrand A, et. al. Preoperative Staphylococcus aureus Carriage and Risk of Surgical Site Infection After Cardiac Surgery in Children Younger than 1 year: A Pilot Cohort Study. Pediatr Cardiol. 2017 Jan;38(1):176-83. https://doi.org/10.1007/s00246-016-1499-z

29. Ben-Ami E, Levy I, Katz J, Dagan O, Shalit I. Risk factors for sternal wound infection in children undergoing cardiac surgery: a case-control study. J Hosp Infect. 2008 Dec; 70(4):335-40.

https://doi.org/10.1016/j.jhin.2008.08.010 